\title{
Obrazy, widma i powidoki umarłych w twórczości Tadeusza Różewicza
}

Bartosz Kowalik

TEKSTY DRUGIE 2021, NR 3, S. 272-289

DOI: 10.18318/td.2021.3.18 | ORCID: 0000-0003-1194-3277

$\mathbf{T}$

wórczość Różewicza jest pełna umarłych. Od debiutanckiego Niepokoju do tekstów z ostatniego okresu jego pisarstwa zmieniało się wiele, ale nie można powiedzieć, że obrazy umarłych, które pojawiły się w debiutanckim tomie w którymś momencie zniknęły. Co jeszcze istotniejsze, nie mamy tu jednak do czynienia z prostą, liniową repetycją tych samych wątków. Nie umknęło to oczywiście uwadze krytyków i badaczy jego twórczości - najbardziej interesujący i aktualny wydaje się artykuł Tomasza Kunza Nekrografie ${ }^{1}$, który będzie dla mnie jednym z istotnych punktów odniesienia, choć zamierzam potraktować problem obrazu umarłych w twórczości Różewicza nieco inaczej. Zamiast skupiać się na makabrycznych przedstawieniach zniszczonego w wyniku wojny ludzkiego ciała, skoncentruję się na znikaniu i powracaniu widoków umarłych oraz konsekwencjach tego zjawiska. O ile bowiem stwierdzenie obecności zmarłych
Bartosz Kowalik student polonistyki antropologiczno-kulturowej w ramach MISH na Uniwersytecie Jagiellońskim. Interesuje się dwudziestowieczną poezją, współczesną filozofią oraz relacjami między literaturą a filozofią.

1 T. Kunz Nekrografie, "Wielogłos” 2013 nr 1, s. 33-46. 
wśród ważnych motywów twórczości autora Płaskorzeźby jest traktowane jako truizm, o tyle sądzę, że uzasadnione i poznawczo owocne będzie spojrzenie na ten problem z innej, widmonotologicznej perspektywy. Można powiedzieć, że poważnie potraktuję w ten sposób sugestie poety zawarte w Przygotowaniu do wieczoru autorskiego, gdzie zadeklarowany ateista i materialista stwierdza: „wierzę w obcowanie żywych i umarłych w mojej poezji2" oraz „[umarli] obcują z nami po śmierci, pełni jeszcze życia, które nie stygnie, ale zmienia się w ciepłe popioły"3. Skupię się zatem na tym, co dzieje się na granicy życia i śmierci, na tym, co nieraz przekracza opozycję życie/śmierć - na umarłych powracających jako widma.

Nie będzie moim celem przedstawienie wszystkich umarłych obecnych w utworach Różewicza (co byłoby technicznie trudne - mamy do czynienia z bardzo dużą liczbą różnych tekstów). Postaram się raczej wywieść z wybranych utworów poety strategię, którą można odnieść do jego twórczości w ogóle. Skupię się nie tyle na samych obrazach, ile na konsekwencjach Różewiczowskiego podejścia, swoistego zarażenia poezji zmarłymi, ale nie w sensie turpizmu i fascynacji śmiercią, tylko jako pewnej etycznej konsekwencji. Pokazanie widmowości w utworach autora Płaskorzeźby zamierzam domknąć interpretacją tekstu, w którym umarły jako widmo pojawia się bezpośrednio, czyli nożyka profesora, który zamierzam przeczytać w kontekście refleksji Jacques'a Derridy na temat nawiedzania.

\section{Obrazy i widma}

"Różewicz zrodził się jako poeta Holocaustu - zjawiska wyjątkowego, i takim pozostal" ${ }^{4}$, stwierdza Maria Janion, a Andrzej Skrendo dodaje, że to właśnie wojna „była matrycą wszelkiego doświadczenia transgresywnego, a więc takiego, które nie powinno pozwolić się zasymilować"5. Oczywiście na wczesnym etapie twórczości Różewicza dominują sugestywne obrazy ciał, często zniekształconych, zniszczonych (słynne „furgony porąbanych ludzi" z Ocalonego). Wraz z nimi jednak odnaleźć możemy pierwsze próby głębszego przemyślenia konsekwencji traumatycznego doświadczenia

\footnotetext{
2 T. Różewicz Przygotowanie do wieczoru autorskiego, Warszawa 1971, s. 81.

3 Tamże, s. 79.

4 M. Janion To, co trwa, w: tejże Do Europy tak, ale z naszymi umarłymi, Warszawa 2000, s. 240.

5 A. Skredno Tadeusz Różewicz i granice literatury. Poetyka i etyka transgresji, Kraków 2002, s. 205.
} 
i bardziej złożone relacje z umarłymi. W Niepokoju są dwa interesujące pod tym względem teksty: Do umartego i Uczeń czarnoksiężnika. Do umarłego buduje zasadniczy dychotomiczny podział na żywy podmiot oraz tytułowego umarłego, do którego skierowany jest monolog. Kontrast między życiem a śmiercią Różewicz osiąga za pomocą wyliczenia kolejnych czynności (widzę, słyszę, dotykam itd.), skądinąd bardzo zwyczajnych. Należy zwrócić uwagę, że pomimo kształtowanego przez cały utwór kontrastu oraz wyrażenia explicite w ostatnim fragmencie: „Żyję / i nic nie jest mi tak obce / jak Ty umarły Przyjacielu", Różewicz kształtuje wypowiedź tak, jakby zwracał się do określonej bliskiej osoby, a zwraca się do bliżej niesprecyzowanego, widmowego umarłego (apostrofa „Przyjacielu” nie oznacza raczej zwrotu do konkretnej, choć niewskazanej bliskiej osoby). Zatem pomimo opozycji żywy-umarły mamy tutaj do czynienia z jakąś formą bliskości, która moim zdaniem może być spowodowana poczuciem swoistej wspólnoty - zupełnie tak, jakby podmiot wiersza był bardzo bliski podzielenia losu umarłego, ale zwykły zbieg okoliczności spowodował różnicę, która jest ogromna i funduje silną opozycję. Co chyba najciekawsze, pomimo tej, zdawałoby się, nieprzekraczalnej granicy umarły adresat wiersza nie należy do zamkniętej przeszłości - świadczy o tym następujący fragment: „moja dziewczyna [...] dłonią nakryła mój niepokój / pamięć o Tobie"7. Zupełnie zmienia to obraz życia przedstawionego w utworze: zamiast ekstatycznego, pełnego radości i witalizmu hedonistycznego korzystania z uciech codzienności mamy walkę z powracającym niepokojem związanym z wciąż świeżym wspomnieniem o tytułowym umarłym, które przypomina o traumatycznym doświadczeniu wojennym, ale także ze świadomością, że równie dobrze sam podmiot mógłby nie żyć, w jego przetrwaniu nie ma żadnego wyższego sensu, a przed zostaniem jedną z ofiar dziejowej katastrofy uratował go przypadek. Pamięć o tytułowym umarłym jawi się jako przeszkoda utrudniająca codzienne życie, uniemożliwiająca arkadyjską beztroskę i radość. Mogłoby się wydawać, że jest tak, ponieważ traumatyczne doświadczenie jest bliskie głównie w sensie czasowym, jako świeże wspomnienie, którego podmiot-Różewicz nie może się pozbyć, ale być może z czasem ulegnie ono asymilacji, a podmiot nauczy się żyć pomimo traumatycznej przeszłości czy wręcz w zgodzie $\mathrm{z}$ nią. Tak sądził choćby Błoński, nazywając drugi powojenny tom Różewicza,

6 T. Różewicz Do umarłego, w: tegoż Wybór poezji, Wrocław 2016, s. 17.

7 Tamże. 
Czerwona rękawiczkę, ,dziennikiem rekonwalescencji”" . Sprowadzenie traumy do zwykłej, fizycznej choroby budzi wątpliwości nie tylko ze względu na zupełną nieprzystawalność zranienia fizycznego i psychicznego, ale przede wszystkim ze względu na to, że wojna była dla poety doświadczeniem końca pewnego systemu wartości kultury europejskiej, a z tego „wyleczyć” się nie można.

Wiele lat później Różewicz stwierdzi: „niepokój, który ogarnął mnie w młodzieńczych latach, trwa do dnia dzisiejszego"9. Nie sposób zatem w pełni zgodzić się ze zdaniem Jerzego Kwiatkowskiego, który twierdził, że wojna była kluczem otwierającym, a później zamykającym poezję Różewicza ${ }^{10}$. Wojna może przestała być ważnym elementem twórczości poety w sensie przedmiotowym, ale, jak postaram się pokazać, jej konsekwencje, w tym przypadku szczególnie otwarcie poezji na zmarłych, są obecne w zasadzie do ostatnich tomików poety (choć oczywiście nie należy redukować całej, bogatej i różnorodnej twórczości autora Kartoteki do wierszy o traumie wojennych przeżyć).

Z kolei w wierszu Uczeń czarnoksiężnika czytamy: „Po co otwarłem uszy / napełniły mnie głosy żywe / echa głosów umarłych"11. Oczywiste jest, że tutaj także mamy do czynienia z dychotomią życia i śmierci, jednakże Różewicz pozostawia wartą podkreślenia niejednoznaczność - głosy żywe albo są echami głosów umarłych, albo są od nich różne, występują, by tak rzec, niezależnie od siebie. Tak czy inaczej głosy umarłych są uobecniane w teraźniejszości poprzez echo. Jak zauważa Jakub Momro, samo echo ma widmowy charakter: "nie jest bowiem istotne, kto mówi i kogo obrazuje akustyczna reprezentacja, lecz to, w jaki sposób dźwięk automatyzuje się w czasie"12. Echo zatem odrywa się od źródła dźwięku, trwa samoistnie przez repetycję tego, czego już nie ma, coraz bardziej zbliżając się do ciszy. Przenosząc te rozważania na płaszczyznę twórczości Różewicza, możemy dojść do wniosku, że przytoczona wyżej sytuacja liryczna dotyczy obecności umarłych w tekstach poety - echo ich głosów będzie uniemożliwiało pisanie lirycznych pieśni.

8 Zob. A. Skrendo Przodem Różewicz, Warszawa 2012, s. 19. Jak miało się później okazać, autor Odmarszu nie doczekał się „rekonwalescencji” poety, co doprowadziło do niechęci Błońskiego wobec autora Niepokoju i oskarżania go o nihilizm.

9 Słowa pochodzą z wykładu Różewicza wygłoszonego z okazji otrzymania tytułu doktora honoris causa Uniwersytetu Śląskiego: http://gazeta.us.edu.pl/node/240941 (dostęp: 20.12.2018).

10 J. Kwiatkowski To jednak co trwa. O wierszach Tadeusza Różewicza „ „Odra” 1983 nr 5, s. 54.

11 T. Różewicz Uczeń czarnoksiężnika, w: tegoż, Wybór poezji, s. 22.

12 J. Momro Echo i medium, "Teksty Drugie” 2016 nr 2, s. 41. 
Innym tekstem, o którym należy wspomnieć, jest poemat Równina z 1954 roku, a więc z okresu stosunkowo bliskiego wojnie. Tytułowy utwór jest zbiorem wojennych reminiscencji, m.in. twarzy zamordowanego przez gestapo brata, zabitych warszawskich poetów czy likwidacji radzieckiego obozu jenieckiego. Co istotne, Różewicz ponownie tematyzuje także swoją relację z umarłymi:

Nie odciąłem się od nich

wbrew pozorom

Nie ja ich trzymam

ale oni mnie zaciskają

Zamordowani Sprawiedliwi

trzymają mnie w otwartych dłoniach

I nie odchodzę

uległy

ich bezbronności. ${ }^{13}$

Zwróćmy uwagę na paradoks, który jest dominantą kompozycyjną i semantyczną tego fragmentu. Umarli, którzy trzymają podmiot w otwartych dłoniach, są określani jako bezbronni, a w rzeczywistości w tej relacji to on jest uległy i bezbronny. Widać wyraźnie podkreślaną inicjatywę $\mathrm{w}$ tej relacji: to nie podmiot wciąż pozostaje przy nich, ale przeciwnie, to oni nie dają o sobie zapomnieć. Określenie "Zamordowani Sprawiedliwi" z powodu braku interpunkcji staje się niejednoznaczne, nie wiemy, czy oba człony należy od siebie oddzielić, czy też traktować jako nierozłączną całość. Jakąś podpowiedzią może być dalsza cześć poematu, w której polegli w wojnie zostają zestawieni z nazwiskami Morgana, Rockefellera, Kruppa czy Cloya - tymi, którzy „nie słyszeli tego strzału / i nie widzieli tej śmierci"14. Przedsiębiorcy i politycy przywołani przez Różewicza mieli różne powiązania z drugą wojną światową, z pewnością nikt nie określiłby ich życiorysów jako nieskazitelnych. W zestawieniu z nimi anonimowi zamordowani rzeczywiście są sprawiedliwi, a zatem uporczywe trwanie przy nich/z nimi/wśród nich ma dwojakie znaczenie. Przed wszystkim wiąże się z reminiscencjami związanymi z traumatycznym przeżyciem.

T. Różewicz Równina, w: tegoż Wybór poezji, s. 118. 
Co jednak istotniejsze, trwanie przy „Zamordowanych Sprawiedliwych” ma charakter wyraźnie aksjologiczny - trwanie przy zgładzonych oznacza trwanie przy etycznym przekonaniu, że o wojnie nie możemy zapomnieć, ściślej: nie możemy zapomnieć o tym, co do niej doprowadziło. Dlatego też, gdy czytamy: „Więc trzeba chodzić / ze wszystkimi latami / z obrazami które widziałem / krajobrazami które opuściłem / Z ręką gestapowca na twarzy brata / z wszystkimi twarzami umarłych [...]"15, słowo „trzeba” jest zarazem określeniem czegoś, czego pozbyć się nie można - traumatycznych obrazów z przeszłości, ale również etycznym imperatywem - tych obrazów zapomnieć nie wolno. Na podstawie zaprezentowanych tutaj przykładów, jak sądzę reprezentatywnych, możemy zatem w twórczości Różewicza wyróżnić, by tak rzec, dwie linie, dwa nurty przywoływania obrazów umarłych, które oczywiście są ze sobą powiązane i niesprzeczne. Pierwszy wiązałby się z traumatycznym doświadczeniem wojennym, reminiscencjami, szczególnie częstymi w początkowej fazie twórczości. Drugi natomiast $\mathrm{z}$ aspektem etycznym - przekonaniem, że wojna była cezurą w dziejach kultury europejskiej, wydarzeniem, które skompromitowało dotychczasowe systemy aksjologiczne, a jej konsekwencje będą istotne dla zrozumienia tendencji tej kultury wiele lat po jej zakończeniu.

W związku z drugą wskazaną tutaj strategią tekstem, w którym Różewicz szczególnie ciekawie werbalizuje swoją relację z umarłymi i który niejako uzasadniania podejmowaną $\mathrm{w}$ tym tekście próbę innego spojrzenia na obrazy umarłych w jego twórczości, jest Wiersz pisany o świcie z tomu Twarz trzecia, a zwłaszcza jego następujący fragment:

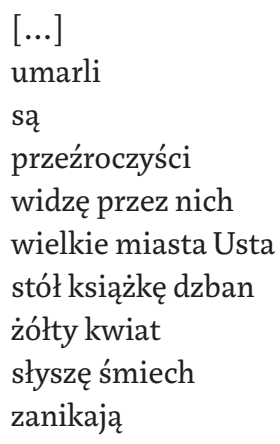

Tamże, s. 114 
to znów gęstnieją

zarastają świat ${ }^{16}$

Umarli mają tutaj wyraźnie wizualną postać, choć jednocześnie, nieco paradoksalnie, są niewidoczni. Uczestniczą jednak w postrzeganiu innych obiektów sytuujących się po obu stronach dialektyki natury („żółty kwiat”) i kultury („stół książkę dzban") - dotyczy to zarówno często występujących w ówczesnych tekstach Różewicza obrazów współczesnych miast, jak i kobiecych ust, które są tutaj synekdochą erotyzmu. Jedynie kontakt z innymi ludźmi („słyszę śmiech”) pozwala na pozbycie się upiornych obrazów, choć tylko chwilowo i w gruncie rzeczy nieskutecznie, o czym świadczy niedokonany aspekt czasownika („zanikają" zamiast „znikają”) oraz słowo „znów” wyraźnie sugerujące ruch powtarzania. Widać wyraźnie paralelę z wierszem $D o$ umarłego z Niepokoju, choć oba teksty dzieli prawie dwadzieścia lat: obcowanie z żywymi ludźmi pozwala (chociaż na moment) oderwać się od obcowania $\mathrm{z}$ umarłymi, staje się jedynym możliwym remedium. Wiersz pisany o świcie nie jest jednak tylko kontynuacją pewnego wątku. Umarli przestają być wyłącznie motywem czy zwerbalizowanym przedmiotem wiersza, stając się nieusuwalną mediatyzacją podmiotowego postrzegania, zajmującą miejsce między podmiotem a jakimkolwiek obrazem.

Można tutaj zauważyć pewne podobieństwo do teorii powidoków Władysława Strzemińskiego ${ }^{17}$, która nota bene zostaje przywołana w poezji Różewicza wprost, do czego jeszcze wrócę. Zdaniem Strzemińskiego ludzkie postrzeganie ma specyficzny charakter: powidok jest obrazem wewnętrznym, który pozostaje na siatkówce oka po przeniesieniu wzroku na inny kształt, jest śladem po obrazie uprzednio oglądanym uobecniającym się w obrazie postrzeganym obecnie ${ }^{18}$. Odnosi się zatem do widmowości par exellence, rozbijając dialektykę obecności i nieobecności przez połączenie ich w nierozerwalnym splocie w samym momencie postrzegania. Dodać do tego należy

T. Różewicz Wiersz pisany o świcie, w: tegoż Poezja, t. 2, Kraków 1988, s. 165.

17 Choć należy uzupełnić, że Teoria widzenia Strzemińskiego zostaje opublikowana dopiero w 1958 roku. Wątek relacji Strzemińskiego i Różewicza wymaga oczywiście szczegółowych badań, w których należałoby zwrócić uwagę także na pozycję Juliana Przybosia - poetyckiego mistrza Różewicza i przyjaciela Strzemińskiego, w którego poezji dostrzegano pewne podobieństwa z obrazowaniem Strzemińskiego. Na temat relacji Przybosia i Strzemińskiego zob. B. Sienkiewicz Strzemiński, Przybośi konstruktywizm, „Pamiętnik Literacki” $1992 \mathrm{nr} 4$. 
dość złożony i nie do końca jasny stosunek Różewicza do obrazu: poeta jednocześnie posługuje się nim i się z nim zmaga ${ }^{19}$, deklaruje konieczność przezwyciężenia go i przekazywania „zdarzeń w świecie uczuć" ${ }^{20}$, w postaci czystej, bez estetyzującej mediacji. Rysuje się tutaj zatem podwójne zapośredniczenie: po pierwsze, związane z obrazowością jako taką, po drugie - z niemożnością pozbycia się powracających, traumatycznych obrazów z przeszłości. Jeśli przeniesiemy tę metaforę na rozumienie powojennej rzeczywistości przez Różewicza, okaże się, że mamy do czynienia z następującą sytuacją: obrazy umarłych są powidokiem, słabiej bądź mocniej obecnym, widmem, które zjawia się nie tyle w chwili pisania tekstu, ile go poprzedza, niekoniecznie jest bezpośrednio w utworach tematyzowane, lecz jednak stanowi istotną podbudowę wierszy. Oczywiście temat obecności wojny w późniejszych utworach Różewicza i struktury relacji przeszłości i teraźniejszości był już przez badaczy podejmowany: Aleksandra Ubertowska określa strategię poety jako „przepisywanie"21, a Robert Cieślak wskazuje na jej palimpsestowy charakter ${ }^{22}$. Oba te ujęcia ściśle łączą się z intencjonalną działalnością tekstotwórczą (pisanie nowych utworów i przekształcanie wcześniejszych), a przywołanie w tym kontekście pojęcia powidoku pozwalałoby na uchwycenie szczególnej formy czasowości, w której każda chwila naznaczona jest anachronizmem: przeszłość wciąż powraca, choć jej czas przeminął. W palimpseście z kolei to, co minione, porządkowane jest w postaci geologicznej stratyfikacji warstw.

Zmarli jako powidoki, obrazy umarłych jako preobrazy dopełniające Różewiczowskie postrzeganie rzeczywistości muszą rzutować na odczytanie jego tekstów, nawet (a może zwłaszcza) tych, w których się nie pojawiają, np. poematów z lat 6o. i 70. Wspomnijmy tylko: „wielkie miasta” z Wiersza pisanego o świcie to zarazem pierwsze słowa i niezwykle ważny motyw poematu Zielona róża, należącego do najistotniejszych utworów dla tzw. Różewiczowskiej krytyki kultury masowej i jednocześnie jednego z pierwszych tekstów, w których wyraźnie widoczne jest Nic, powód oskarżenia poety o etyczny nihilizm i zarazem motyw należący do najbardziej niejednoznacznych jego twórczości. Nie sposób takich oskarżeń formułować, jeśli weźmie się pod

19 T. Różewicz Przygotowanie do wieczoru autorskiego, s. 99.

Tamże.

Zob. A. Ubertowska Tożsamość jako ślad kryptograficzny (Holokaust w późnych poematach Tadeusza Różewicza), w: tejże Świadectwo - trauma - głos. Literackie prezentacje Holokaustu, Kraków 2007, s. 126-130. 
uwagę, że owo Nic powstaje w przestrzeni, na którą patrzy się przez pryzmat przezroczystych umarłych.

\section{Zaniepokojenie - Różewicz o przełomie wieków}

Obraz obcowania z umarłymi, nawiedzającymi Różewicza widmami byłby niepełny bez przeanalizowania tej kwestii w nożyku profesora, który potraktuję jako konfrontację z widmami, swego rodzaju domknięcie widmowego wątku jego twórczości. Tekst ten doczekał się wielu komentarzy, głównie dotyczących znaczenia przedmiotów w upamiętnieniu Zagłady ${ }^{23}$, nie zwrócono jednak dotychczas uwagi na kluczowy w mojej opinii aspekt spektralny. Skupię się na spotkaniu z Różą, które w opinii badaczy jest najważniejszym momentem poematu² ${ }^{24}$ Przedstawię tutaj wspomnianą Różę jako widmo, pewną matrycę pojawiania się umarłych w poezji Różewicza. Róża jest oczywiście nawiązaniem do jednego z pierwszych wierszy debiutanckiego Niepokoju, w którym czytamy, że: „Róża to kwiat / albo imię umarłej dziewczyny” 25 . Jednak to samo imię pojawia się we wspomnianym już, ważnym dla relacji poety z umarłymi poemacie Równina, w którym czytamy o Róży idącej przez opustoszałe ulice (oprócz Żabiej w polskim mieście są to ulice miast i miasteczek w neutralnych Szwecji i Szwajcarii), by w końcu zniknąć, przejść „jak przechodzą chmury". Ponadto Różewicz podsumowuje jej obecność w tekście następującym fragmentem: „przechowałem w sobie / uderzenia jej serca / milczenie oczu / ciepło i barwę ust [...]"26. Dodać należy jeszcze uwagę, którą mimochodem poczynił w Przygotowaniu do wieczoru autorskiego: „Muszę też wspomnieć [...] o nieznajomej umarłej, która leży pod drewnianą ścianą baraku. Piękna, naga, z czarnymi włosami w śniegu"27. Ten opis jest opisem kobiety, której zdjęcie zostało umieszczone na pierwszej stronie nożyka profesora - jego bohaterki Róży ${ }^{\mathbf{2 8}}$. Z tekstów tych możemy zatem wywnioskować,

Zob. np. B. Shallcross Przedmioty Zagłady po Zagładzie, w: tejże Rzeczy iZagłada, Kraków 2010.

Zob. A. Ubertowska Tożsamośćjako ślad kryptograficzny, s. 126-128; B. Krupa Ciało Róży. Fotograficzne reprezentacje Zagłady w "nożyku profesora”, w: Niepokoje. Twórczość Tadeusza Różewicza wobec Zagłady, red. P. Krupiński, Warszawa 2014.

T. Różewicz Róża, w: tegoż Wybór poezji, s. 5.

T. Różewicz Równina, w: tegoż Wybór poezji, s. 120.

T. Różewicz Przygotowanie do wieczoru autorskiego, s. 114.

Zob. B. Krupa Ciało Róży; R. Cieślak Widzenie Różewicza, s. 26-29. 
że Róża, o której mowa w nożyku, jest widmem zmarłej dziewczyny pojawiającym się tu z konkretnego powodu. Nie dziwi więc przygotowanie gruntu na spotkanie z nią przez przywołanie tekstu, który chyba najbardziej kojarzy się z pojawieniem niepokojącego ducha, czyli Szekspirowskiego Hamleta:

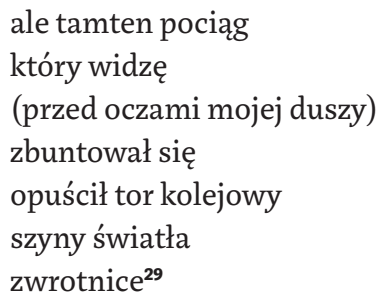

Jak wiadomo, przyjście ducha w dramacie Szekspira spowodowane było dokonaną na królu bratobójczą zbrodnią, która nie została pomszczona. Jednocześnie pojawienie się zmarłego napędza całą akcję, staje się początkiem działań Hamleta prowadzących do odkrycia prawdy i wymierzenia sprawiedliwości. Derrida prezentuje swój sposób myślenia na temat widm, interpretując właśnie tę scenę. Zatem spróbujmy przeczytać nożyk profesora w kontekście Derridiańskiego myślenia o widmach, logice nawiedzania i egzorcyzmowania. Zanim jednak przejdziemy do samego spotkania, zastanówmy się nad wewnętrznym i zewnętrznym czasem tekstu, innymi słowy, nad pewnym sposobem myślenia o porządku temporalnym obecnym w utworze oraz nad okolicznościami zewnętrznymi, kontekstem ważnym dla jego powstania.

Zarówno nożyk profesora, jak i Widma Marksa Derridy powstały w związku $\mathrm{z}$ bardzo konkretnymi sytuacjami historycznymi, a co istotne, niemal w tym samym okresie - dzieli je zaledwie siedem lat. Tekst Derridy (1994) stanowi odpowiedź na ogłoszony przez Fukuyamę koniec historii, do którego miało dojść wraz z triumfem liberalnego kapitalizmu i zachodniej demokracji - jest wyrazem przekonania, że ,the time is of joint", czas wypadł z kolein ${ }^{30}$. Filozof wymienia dziesięć „plag nowego porządku świata” ${ }^{31}$, z którymi musimy

29 T. Różewicz nożyk profesora, Wrocław 2001, s. 22. Oczywiście przywołanie Hamleta następuje z pośrednictwem Mickiewiczowskiej Romantyczności, innego widmowego tekstu. Sytuacja w poemacie jest jednak znacznie bliższa tragedii Szekspira.

31 Są to: bezrobocie, masowe wykluczenie bezdomnych obywateli, wojna ekonomiczna, sprzeczności związane z wolnym rynkiem, pogłębianie zadłużenia, handel bronią, szerzenie się broni 
się zmierzyć. Również Różewicz na przełomie XX i XXI wieku dostrzega alarmujące zjawiska - wzrost tendencji nacjonalistycznych, oddzielenie moralności od sfer życia publicznego (polityki i nauki), a przede wszystkim niepokojący proces zapominania o Zagładzie. Wyrazem tego jest poemat recycling, w którym refrenicznie powraca fraza "a może holokaustu nie było?", w posłowiu do poematu zaś czytamy: „Ani «sumienie», ani zdrowy rozum nie dają żadnej gwarancji, że ludzie nie będą fabrykować taśmowo ciał ludzkich

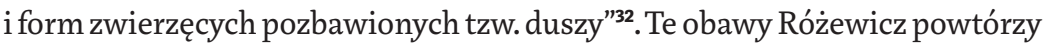
i doprecyzuje w kolejnym tomiku - nożyku profesora. Ubertowska słusznie proponuje, żeby czytać te dwa poematy jako dyptyk, wskazując na wspólne motywy: Owidiuszowych przemian, złota i żelaza ${ }^{33}$. Nieco tę propozycję zmodyfikujmy, traktując recycling jako gorzką diagnozę tego, co dzieje się na przełomie wieków, a więc siłą rzeczy dotyczy teraźniejszości, natomiast nożyk jako kontynuację tej diagnozy, przemyślenie jej konsekwencji oraz rozszerzenie chronologii. $Z$ tej perspektywy widać zatem pewne podobieństwo w myśleniu Derridy i Różewicza - silne przekonanie, że na świecie nie dzieje się tak, jak powinno, i należy coś z tym zrobicín ${ }^{34}$.

Przejdźmy teraz do problemu chronologii wewnątrz tekstu. Andrzej Skrendo, wskazując na umieszczone w brulionowej wersji tekstu datowanie: „1950-2001”, stwierdził, że poeta „spina klamrą całe półwiecze i stawia diagnozę na początek wieku XXI"35. W nożyku profesora, którego interpretacje są skupione wokół przeszłości ${ }^{36}$, nie mamy do czynienia z prostym ujęciem struktury chronologicznej. W tekście odnajdziemy teraźniejszość (fragment Jajko Kolumba), przeszłość oraz pewien zwrot ku przyszłości, relacje pomiędzy poszczególnymi temporalnymi modalnościami nie są jednak proste i oczywiste. Pisze Derrida:

nuklearnej, wojny wewnątrzetniczne, kartele narkotykowe i stan prawa międzynarodowego. Zob. tamże, s. 138-146.

T. Różewicz recycling, w: tegoż Wybór poezji, s. 771.

A. Ubertowska Tożsamość jako ślad kryptograficzny, s. 130-131.

Należy przy tym jednocześnie dodać, że zawiera się tutaj także pierwsza, bardzo istotna różnica: Derridzie idzie o gruntowną zmianę sposobu myślenia na temat polityczności i sprawiedliwości, Różewiczowi zaś o pamięć. 
Skoro istnieje coś takiego jak widmowość, to istnieją też powody, by wątpić w ten upewniający i uspokajający porządek teraźniejszości, a nade wszystko w istnienie granicy pomiędzy teraźniejszością, aktualną, obecną realnością tego, co teraźniejsze, a tym wszystkim, co można jej przeciwstawić: absencją, nieobecnością, nierzeczywistością, nieaktualnością, wirtualnością, a nawet symulakrum w ogóle itd. Chodzi przede wszystkim o to, aby podać w wątpliwość współczesność tego, co teraźniejsze z samym sobą. Nie wiedząc jeszcze, czy możliwe jest odróżnienie widma przeszłości i widma przyszłości, przeszłej teraźniejszości i przyszłej teraźniejszości, powinniśmy być może zastanowić się, czy efekt widmowości nie podważa tej opozycji, a nawet dialektyki, pomiędzy rzeczywistą obecnością i tym, co względem niej inne. ${ }^{37}$

Obcowanie z widmami, logika nawiedzania powoduje, że klarowne oddzielenie od siebie przeszłości, teraźniejszości i przyszłości jest niemożliwe, a co za tym idzie, nie można traktować przeszłości jako zamkniętego archiwum, które nie ma bezpośredniego wpływu na aktualność, oraz przyszłości jako czegoś, co dopiero nadejdzie i w związku z tym nie dotyczy teraźniejszości. Jak pisze Jakub Momro: „Chodzi [...] o wskazanie na przechodni charakter teraźniejszości, która nie jest prostą i całkowitą obecnością, lecz stanowi nieustanny ruch «tam i z powrotem»"38, w którym teraźniejszość lokuje się spójniku.

Przejdźmy do samego poematu: Różewicz w nożyku profesora opisuje pociąg jadący po zupełnie naturalnym, nieskażonym cywilizacją krajobrazie. W pewnym momencie trzecioosobowa, epicka wręcz narracja zostaje przerwana, a podmiot liryczny z obserwatora staje się uczestnikiem wydarzeń, zostaje niespodziewanie w nie wciągnięty:

czy to już Treblinka

pyta mnie młoda

w pełnej wiośnie lat

Dziewczyna

przypominam sobie

jej usta

i oczy jak garść fiołków

to Róża z Radomska...

37 J. Derrida Widma Marksa, s. 75.

38 J. Momro Widmontologie nowoczesności. Genezy, Warszawa 2014, s. 476. 


$$
\begin{aligned}
& \text { „Zwałem ją Różą } \\
& \text { iż trzeba było nazwać } \\
& \text { więc jest nazwana” } \\
& \text { jak miała na imię } \\
& \text { nie pamiętam³ }
\end{aligned}
$$

Podmiot wiersza zostaje zagadnięty przez tajemniczą Różę, pytanie zmusza go do odpowiedzi, a jak pisał Levinas, bycie zagadniętym przez Innego jednocześnie poprzedza etyczną relację i ją rozpoczyna, umożliwiając sprawiedliwość. Od początku zostaje więc zawiązana sytuacja etyczna, która będzie ważna w kontekście całej interpretacji.

Jako się rzekło, Róża jest widmem, staje się jednak paradoksalnie widzialna - wiemy, że ma „usta/I oczy jak garść fiołków”. Odpowiedź na ten paradoks znajdziemy u Derridy: „widmo jest paradoksalnym wcieleniem, stawaniem-się-ciałem, pewną zjawiskową i cielesną formą ducha. Staje się ono pewną

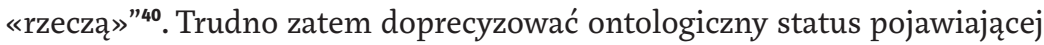
się w pociągu dziewczyny, tym bardziej że chwiejna jest jej tożsamość - nie ma własnego imienia, a imię, które arbitralnie nadaje jej podmiot-rozmówca jest w twórczości Różewicza metonimią nie tyle samej śmierci, ile martwej dziewczyny ${ }^{41}$. Spotkanie z nią zostaje przerwane równie nagle, jak się rozpoczęło - rozpoznanie sprawia, że zostaje zastąpiona przez postać „Aliny rzeźbiarki":

przecież to Alina myślę

Alina rzeźbiarka uczennica Xawerego Dunikowskiego w wagonie bydlęcym otwiera okno wychyla się całuje wiatr zamyka okienko okaleczone

39 T. Różewicz nożyk profesora, s. 22-23.

J. Derrida Widma Marksa, s. 24.

Róża to imię martwej dziewczyny, nie zaś martwa dziewczyna. Różewicz podkreśla językowość pamięci, pokazując przy tym przenikanie życia i śmierci. Zwraca uwagę, że wieloznaczność języka może być czynnikiem zarówno pamięć podtrzymującą, jak i przyczyniającą się do zapominania. 


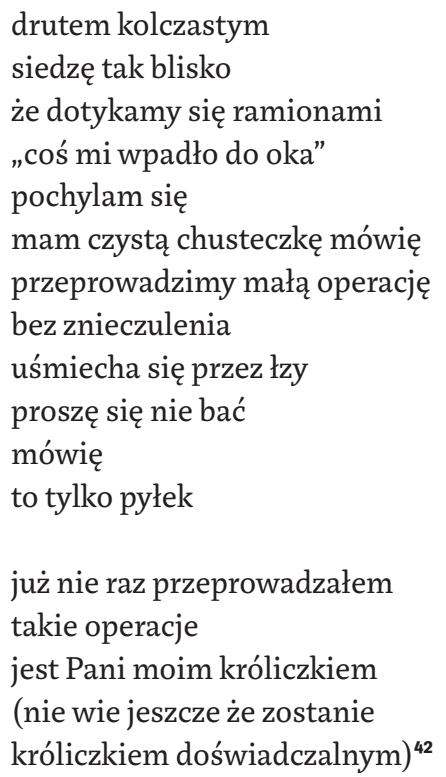

Sugerowałoby to następującą sytuację: widmo-Róża zostaje zdemaskowane, rozpoznane, a przez to zneutralizowane, wyegzorcyzmowane, zastąpione wspomnieniem wspólnej podróży z rzeźbiarką, w której i tak dostrzegamy powidok jej przeszłości, związanej z pobytem w obozie koncentracyjnym. Jednakowoż Róża znika tylko na moment, by po chwili ponownie powrócić:

pani pozwoli że się przedstawię

mam na imię Tadeusz

a ja Róża... jedziemy z Mamą

z Teresina do Treblinki

Mama jest w wagonie restauracyjnym

rozdzielili nas

tamten wagon jest na końcu

wysiadamy w Treblince

wie Pan umieram z głodu

naprawdę umieram

42 T. Różewicz nożyk profesora, s. 23-24. 
jestem taka głodna

że zjadłabym konia z kopytami

albo marchewkę

brukiew

głąb kapuściany

...a Pan gdzie jedzie? Jeśli można wiedzieć

ja? Ja tak sobie! Do lasu

na grzyby na jagody

na świeże powietrze

jestem Satyr

dziewczyna roześmiała się

teraz już mogę pani zdradzić

wysiadam na najbliżej stacji

miejsce postoju oddziału nazywa się

„wysokie drzewa"43

Kluczowe pytanie dotyczy tego, skąd w ogóle Róża bierze się w pociągu, a co za tym idzie w tekście. Odpowiedź znaleźć możemy u Derridy, który stwierdza, że widmo pojawia się w sytuacji niesprawiedliwości w stosunku do Innego. Odnosząc to do nożyka profesora, możemy zbudować następującą interpretację: Różewicz jest tym, który otarł się o śmierć i jednocześnie jest nawiedzany przez widma nienazwanych już-umarłych oraz pochodzące z przyszłości widma, które mogą stać się widmami masowego produkowania śmierci. Oprócz tego zmaga się z fantomem własnej śmierci, która tutaj pojawia się zakamuflowana w konspiracyjnym pseudonimie poety - Satyr. Ożywiona dyskusja, dotycząca tego, czy Różę możemy utożsamiać z Różewiczem (jak proponowała Ubertowska ${ }^{44}$ ), podzieliła badaczy, ja skłaniam się ku następującemu rozwiązaniu: Różewicz-Satyr (czyli ten kto ostatecznie przeżył) to nie Róża (która zginęła), choć żyje w przekonaniu, że był bardzo blisko podzielenia jej losu bez względu na to, czy stałby się jedną z ofiar Zagłady (ze względu na żydowskie pochodzenie jego matki), czy jedną z ofiar

Tamże, s. 24-25. 
działań wojennych ${ }^{45}$. Stan podmiotu z nożyka profesora określiłbym mianem zaniepokojenia: z jednej strony ów niepokój bierze się z tego, co już doświadczone, co odchodzi i powraca (np. w postaci obrazów umarłych), z drugiej zaś z tego, co potencjalne - z możliwości powtórzenia masowej zbrodni, do czego prowadzi negacja i zapomnienie o Zagładzie. Różewicz nie jest więc poetą regresji, turpizmu czy wreszcie nihilizmu, ale w tekstach takich jak nożyk profesora kształtuje, by tak rzec, minimalistyczną etykę, minima moralia, jak to określał Adorno, której imperatywem kategorycznym byłoby niedopuszczenie do kolejnej masowej zbrodni: „Hitler narzucił ludziom w sytuacji ich zniewolenia nowy imperatyw kategoryczny: myśleć i działać tak, aby nie powtórzył się Oświęcim, aby nie zdarzyło się już nic podobnego"46. Powszechny proces zapominania i negowania Zagłady (symbolizowany w tekście przez boga rdzy Robigusa) prowadzi do zaniepokojenia, a także do nawiedzania przez widma umarłych. Bez pamięci o nich i oddania im sprawiedliwości (poprzez uniemożliwienie kolejnych zbrodni) nigdy nie nauczymy się żyć, jak powiadał Derrida, ponieważ wciąż jesteśmy nawiedzani.

$\mathrm{Na}$ koniec sformułujmy bardziej ogólną refleksję dotyczącą czegoś, co można roboczo określić widmowością Różewicza. Sądzę, że interesujące byłoby ponowne przywołanie teorii powidoków, która pojawia się bezpośrednio w nożyku: tłumaczy ją Różewiczowi Przyboś, co zresztą ma oparcie w rzeczywistości, Przyboś był bowiem autorem przedmowy do Teorii widzenia Strzemińskiego. Sądzę, że powidoki są kluczem do zrozumienia tego, jak Różewicz postrzega relacje między historycznością a aktualnością, i to nie tylko w nożyku profesora, choć w tym poemacie uwidacznia się to najwyraźniej. Gdyby chcieć wyobrazić sobie coś w rodzaju teorii postrzegania kultury według Różewicza, byłaby ona na wskroś historyczna, ale nie w prostym, hermeneutycznym sensie rezerwuaru symboli koniecznych do rozumienia teraźniejszości, lecz jako coś widmowego właśnie, jako przestrzeń stale nawiedzana przez duchy, które w teraźniejszości wciąż się uobecniają czy wręcz uniemożliwiają podział na przeszłość, teraźniejszość i przyszłość, gdyż, jak wiemy od Derridy, widmo przychodzi zawsze w imię tego, co dopiero ma nadejść.

45 Decyduję się tutaj na uznanie Zagłady za rdzeń i tę część doświadczenia wojennego, której nie da się zasymilować. Zob. T. Kunz Nekrografie , "Wielogłos” 2013 nr 1, s. 33-46.

46 T. Adorno Dialektyka negatywna, przeł. K. Krzemieniowa, Warszawa 1986, s. 513. 


\section{Podsumowanie}

Przedstawione tutaj spojrzenie na obrazy umarłych w twórczości Różewicza oczywiście nie wyczerpuje tematu, raczej przeciwnie: miało być próbą zaprezentowania nieco innego sposobu lektury wybranych tekstów autora Kartoteki. Starałem się pokazać, że umarli w utworach poety nie występują tylko w postaci makabrycznych zwłok z pierwszych tomików. Chodziło mi raczej o zastanowienie się nad takim ich przedstawieniem, które nie byłoby reminiscencją traumatycznych przeżyć, innymi słowy: nad funkcją i znaczeniem obecności (lub nieobecności) umarłych w różnych wierszach Różewicza. Doszedłem do wniosku, że funkcjonalne może okazać się zrezygnowanie z dychotomicznego podziału na obecność i nieobecność, dlatego zdecydowałem się na przeczytanie nożyka profesora w kontekście Widm Marksa Derridy jako opowieści o zaniepokojeniu i widmie, które przychodzi w imię absolutnej sprawiedliwości.

Widmowość jako sposób widzenia rzeczywistości doprowadziła mnie do przekonania, że zmarli w twórczości Różewicza pojawiają się w związku z imperatywem etycznym, interpretacja nożyka profesora w perspektywie widmontologii dowodzi, że poeta bynajmniej nie jest nihilistą w sensie etycznym, a niestety takie przekonanie wciąż istnieje w powszechnej świadomości. Jeśli zaś myśli się o etycznym charakterze twórczości Różewicza, trzeba wspomnieć o książce Andrzeja Skrendy Tadeusz Różewicz i granice literatury. Poetyka i etyka transgresji, w której autor rozprawia się z pewnymi mitami dotyczącymi poety i, posługując się teorią transgresji Bataille'a, dowodzi, że Różewicz jest poetą "niepozytywnej afirmacji i aprobatywnej negacji" ${ }^{\text {47 }}$.Zatem autor Niepokoju, czytany w różnych kontekstach teoretycznych, na przykład hauntologii czy transgresywności, bynajmniej nie okazuje się nihilistą czy turpistą.

47 A. Skrendo Tadeusz Różewicz i granice literatury, s. 10. Zob. tamże, s. 313-374. 


\section{Abstract}

\section{Bartosz Kowalik}

JAGIELLONIAN UNIVERSITY (CRACOW)

Images, Spectres and After-Images of the Dead in the Work of Tadeusz Różewicz

Kowalik draws on Jacques Derrida's hauntology to examine the status of the dead in Tadeusz Różewicz's work. In the first part he posits a transition between images of the dead (esp. in the poems written immediately after the war and dealing with traumatic wartime experiences) to their spectral return as what Władysław Strzemiński calls afterimages. Kowalik relates the presence of the dead to questions of ethics, questions of seeing and poetic imaging. In the second part he presents a reading of the poem"nożyk profesora" [The Professor's Knife] in the context of Derrida's Spectres of Marx, highlighting ethical aspects of Różewicz's late work that are reminiscent of Derrida's notion of absolute justice.

\section{Keywords}

Tadeusz Różewicz, spectre, hauntology, Jacques Derrida, afterimage 